For mat i on of vv I acunary pol yoxovanadates and i nt er conver si on reacti ons of dodecavanadate speci es

\begin{tabular}{|l|l|}
\hline 著者 & $\begin{array}{l}\text { Okaya Kenj i , Kobayashi Tet suhi r o, Koyama Yuki , } \\
\text { Hayashi Yoshi hi to, I sobe Ki yoshi }\end{array}$ \\
\hline $\begin{array}{l}\text { j our nal or } \\
\text { publ i cat i on ti t l e }\end{array}$ & Eur opean J our nal of I nor gani c Chem st ry \\
\hline number & 34 \\
\hline page $r$ ange & $5156-5163$ \\
\hline year & $2009-11-02$ \\
\hline URL & ht t p: //hdl . handl e. net /2297/20362 \\
\hline
\end{tabular}




\title{
Formation of V(V) Lacunary Polyoxovanadates and Interconversion Reactions of Dodecavanadate Species
}

\author{
Kenji Okaya, Tetsuhiro Kobayashi, Yuki Koyama, Yoshihito Hayashi," and Kiyoshi Isobe
}

Keywords: Polyoxometalates / Vanadium / Host-guest systems / Template synthesis

Oxidation reactions of the reduced decavanadate, $\left[\mathrm{V}^{\mathrm{IV}}{ }_{2} \mathrm{~V}_{8}^{\mathrm{V}} \mathrm{O}_{26}\right]^{4}$ (1) with halide guest anions have been investigated for the synthesis of $\mathrm{V}(\mathrm{V})$ host molecules. The reaction with $\mathrm{Cl}^{-}$afforded a new dodecavanadate, $\left[\mathrm{HV}^{\mathrm{V}}{ }_{12} \mathrm{O}_{32}(\mathrm{Cl})\right]^{4-}(3)$, which incorporated the guest chloride anion. The polyoxovanadate framework of $\mathbf{3}$ is different from the bowl-shaped dodecavanadate, $\left[\mathrm{V}^{\mathrm{V}}{ }_{12} \mathrm{O}_{32}\left(\mathrm{CH}_{3} \mathrm{CN}\right)\right]^{4-}$ (2). The structure of $\mathbf{3}$ is regarded as a trilacunary counter part of the pentadecavanadate, $\left[\mathrm{V}^{\mathrm{V}} \mathrm{V}^{\mathrm{IV}}{ }_{6} \mathrm{O}_{36} \mathrm{Cl}\right]^{4}$. Employment of a $\mathrm{F}^{-}$template yielded the layered polyoxovanadate, $\left[\mathrm{HV}^{\mathrm{V}}{ }_{11} \mathrm{O}_{29} \mathrm{~F}_{2}\right]^{4-}$ (4). The framework of 4 is a mono-lacunary structure of the fluoride incorporated dodecavanadate, $\left[\mathrm{H}_{6} \mathrm{~V}^{\mathrm{V}}{ }_{2} \mathrm{~V}^{\mathrm{IV}}{ }_{10} \mathrm{O}_{30} \mathrm{~F}_{2}\right]^{6-}$, in which one of the $\mathrm{VO}$ group at the belt ition is removed. The three vanadium atoms in the capping units are connected by $\mu^{3}-\mathrm{F}$ bridges.

\begin{abstract}
Reaction with $\mathrm{Br}^{-}$provided $\left[\mathrm{HV}^{\mathrm{V}}{ }_{12} \mathrm{O}_{32}(\mathrm{Br})\right]^{4-}$ (5) with minor formation of $\left[\mathrm{H}_{3} \mathrm{~V}^{\mathrm{V}}{ }_{10} \mathrm{O}_{28}\right]^{3-}$. Interconversion reactions between $\mathbf{2}, \mathbf{3}$, and $\mathbf{4}$ were proceeded as follows: a) the reaction of $\mathbf{2}$ with $\mathrm{Cl}^{-}$prompted an isomerization reaction of the bowl-type framework affording 3 ; b) the reaction of 3 with $\mathrm{F}^{-}$gave 4 ; c) the reaction of 4 with $\mathrm{CH}_{3} \mathrm{CN}$ reproduced the acetonitrileincorporated 2. Complexes 3 and $\mathbf{4}$ were characterized by X-ray analysis. The polyoxovanadates $\mathbf{3}$ and $\mathbf{4}$, with highest oxidation cores, exhibited distinct signals in the ${ }^{51} \mathrm{~V}$ NMR spectra corresponding to lacunary polyoxovanadate geometries.
\end{abstract}

(C) WILEY-VCH Verlag GmbH \& Co. KGaA, 69451 Weinheim, Germany, 2009) [a] Department of Chemistry, Graduate School of Natural Science and Technology, Kanazawa University, Kakuma, Kanazawa, 920-1192, JAPAN

Fax: +81-76-264-5742

E-mail: hayashi@kenroku.kanazawa-u.ac.jp

Supporting information for this article is available on the WWW under http://www.eurjic.org/ or from the author.

\section{Introduction}

Spherical polyoxometalates have attracted attention due to their unique host-guest interactions and their fullerene-like metal-oxo cages, which are sufficiently large to include various types of guest molecules. ${ }^{[1]}$ For spherical polyoxovanadates, guest molecules are anions positioned inside the anionic polyoxovanadate cage. The topology and the electrostatic potential distribution explain the encapsulation of the anionic guest. ${ }^{[2]}$ The polyoxovanadate cores are constructed by linkages of the square pyramidal $\mathrm{VO}_{5}$ units. The bifunctionality of the square-pyramidal $\mathrm{VO}_{5}$ unit may allow the core to interact either as a cationic or an anionic center. For interaction with a cation, the $\mathrm{VO}_{5}$ unit is able to work as a donor through the negative oxo groups, and for interaction with an anion, the unit may act as an acceptor through the sixth coordination site of the $\mathrm{VO}_{5}$ square pyramidal unit, which has a positive electrostatic charge on the metal, to allow interaction with the anionic guest molecule. ${ }^{[3]}$ For the application of host-guest chemistry, such as the recognition of anions, catalytic reactivity, and molecular transportation, ${ }^{[4]}$ a guest anion that is tightly trapped inside the spherical cage is undesirable, because there is no possibility of guest removal without destruction of the cage. The synthesis of open-cage molecules is required for the creation of further applications. The Klemperer-type half-spherical dodecavanadate, $\left[\mathrm{V}_{12} \mathrm{O}_{32}\left(\mathrm{CH}_{3} \mathrm{CN}\right)\right]^{4-}$ (2) has an open end at the half sphere from which an acetonitrile guest molecule is free to dissociate. ${ }^{[5]}$
Several dodecavanadates with nitriles or $\mathrm{NO}^{-}$guest anions have been reported $^{[6]}$ and the host-guest interactions have been theoretically investigated. ${ }^{[7]}$ The synthesis of dodecavanadate 2 has long been known, and later isolation of the tridecavanadate $\left[\mathrm{V}_{13} \mathrm{O}_{34}\right]^{3-}$ was reported, although the synthetic conditions of the compounds were almost identical with the only difference being the reflux time. ${ }^{[8 a]}$ New and improved synthetic routes are required for further developments in the host-guest chemistry of $\mathbf{2}$. We are currently interested in the cyclic polyoxovanadate species, $\left(\mathrm{VO}_{3}\right)_{\mathrm{n}}{ }^{\mathrm{n}-}$, which are capable of coordination with cationic templates. ${ }^{[9]}$ Metavanadate species have one-dimensional or cyclic structure, ${ }^{[10]}$ which can act as a larger macrocyclic oxo-ligand to metal centers. An example includes the reduced decavanadate (Figure 1) which can be regarded as a dinuclear vanadyl complex with a macrocyclic octadecavanadate ligand. ${ }^{[11]}$ We have recently developed the growth reaction of $\mathbf{1}$ using reduction reactions to increase the size of the core. ${ }^{[12]}$ The redox reaction of polyoxometalates is one of the typical methods used to transform polyoxometalate frameworks. ${ }^{[13]}$ In this paper, we report the oxidation reactions of 1, with or without guest anions, and utilize the cyclic octavanadate framework as a scaffold toward synthesis of a spherical compound.

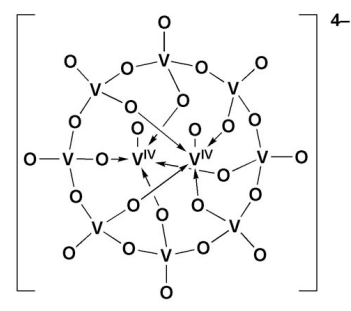

Figure 1. Schematic representation of anion $\mathbf{1 .}$ 
Syntheses of new polyoxovanadates were attempted with the highest oxidation state vanadium atoms. In the course of this study, new types of lacunary polyoxovanadates were discovered with incorporation of fluoride-, chloride-, and bromide-guests. The chloride-incorporated dodecavanadate, $\left[\mathrm{HV}_{12} \mathrm{O}_{32}(\mathrm{Cl})\right]^{4-}(3)$ has a different framework from compound $\mathbf{2}$, and has a new highest oxidation core. Reaction without a guest molecule resulted in the high-yield synthesis of $\mathbf{2}$ by acetonitrile incorporation. Interconversion reactions of these polyoxovanadates by reaction with halide anions were also investigated.

\section{Results and Discussion}

\section{Synthesis}

Polyoxometalate frameworks arise through a balance of electrostatic charge distribution between metal cations and anions. The template directed mechanism is believed to operate in the formation processes of growth reactions from metal-oxo acids. Interaction with an acid causes a condensation reaction of the metal-oxo acids to the oligomers. During the process, even a solvent molecule may be a template, as observed for Klemperer's dodecavanadate, $\left[\mathrm{V}_{12} \mathrm{O}_{32}\left(\mathrm{CH}_{3} \mathrm{CN}\right)\right]^{4-}$ (2). ${ }^{[5]} \quad$ Anion-templated spherical polyoxovanadates have been reported by Müller's group, and the vanadium atoms of those compounds were in a mixed valence state of $\mathrm{V}(\mathrm{VI})$ and $\mathrm{V}(\mathrm{V})$ exhibiting a deep blue color. ${ }^{[14]}$ The anion incorporated spherical polyoxovanadate with all the vanadium atoms in the $\mathrm{V}(\mathrm{V})$ oxidation state is yet unknow. In principle, the affinity between an anionic guest and a polyoxovanadate host can be increased by decreasing the negative charges on the polyoxovanadate host because of less repulsive forces between the anionic guest and the negatively charged polyoxovanadate. For that reason, an all-V(V) cage with lower negative charges, compared to the mixed valence $\mathrm{V}(\mathrm{V}) / \mathrm{V}(\mathrm{IV})$ cage of the same framework, may be produced through oxidation of the reduced polyoxovanadates. To develop new polyoxovanadates with the all- $\mathrm{V}(\mathrm{V})$ cage, we explored oxidation reactions of the reduced polyoxovanadate, $\left[\mathrm{V}_{10} \mathrm{O}_{26}\right]^{4-}(\mathbf{1})^{[11]}$ which is a spherical polyoxovanadate without a guest molecule inside the cage. As a control, reaction in the absence of anionic templates was first attempted to determine the products of oxidation by hydrogen peroxide. In this reaction, despite no guest molecule being added to the mixture, acetonitrile solvent was included in the core of the Klemperer-type dodecavanadate, $2 .^{[6]}$ The synthesis of $\mathbf{2}$ by this method is selective, thus providing an improved route with high yields. From these control experiments, it was revealed that acetonitrile is a good template for the $\mathrm{V}(\mathrm{V})$ polyoxovanadates, and only 2 was formed when using acetonitrile. The use of polar solvents such as nitromethane also produced the bowl-type dodecavanadate, as confirmed from IR spectra. The nitromethaneincorporated dodecavanadate was not crystallized and characterization was not possible. For the inclusion of halide anions in this system, nonpolar solvents and non-aqueous oxidants were required. The best solvent for anion inclusion was found to be dichloromethane which was unlikely to be incorporated into the polyoxovanadate core. To survey the best oxidant, hydrogen peroxide, tert-butyl hydroperoxide, and $m$-chloroperbenzoic acid were examined and tert-butyl hydroperoxide was found to be the best non-aqueous oxidant, although the reaction rate was slower. The products of oxidation and the guest incorporation reaction were reactive with water and the use of aqueous hydrogen peroxide solution inhibited the formation of crystals and yielded only oily products. The reaction of $\mathbf{3}$ with a small amount of water gave an unidentified brown oil. Oxidation of $\mathbf{1}$ by tert-butyl hydroperoxide in dichloromethane produced new types of lacunary polyoxovanadates with various halide anion templates. The reaction in the presence of the $\mathrm{Cl}^{-}$template afforded a new type of spherical dodecavanadate, $\left[\mathrm{HV}_{12} \mathrm{O}_{32}(\mathrm{Cl})\right]^{4-}$ (3), with a different framework from that of 2, with $35 \%$ yield. Employment of the $\mathrm{F}^{-}$ template gave the fluoride-incorporated $\left[\mathrm{HV}_{11} \mathrm{O}_{29} \mathrm{~F}_{2}\right]^{4-}$ (4) with $54 \%$ yield. For the crystallization of 4 , addition of chloroform to the concentrated dichloromethane solution was necessary (see experimental section). Reaction with $\mathrm{Br}^{-}$gave $\left[\mathrm{HV}_{12} \mathrm{O}_{32}(\mathrm{Br})\right]^{4-}(\mathbf{5})$ with $15 \%$ yield and with minor formation of the decavanadate, $\left[\mathrm{H}_{3} \mathrm{~V}_{10} \mathrm{O}_{28}\right]^{3-}$. [15] Interestingly, crystallization of the complexes required addition of hydrochlorocarbon solvents such as dichloromethane or chloroform and hydrophobic interactions may control the crystallization of these compounds. The reaction with $\mathrm{I}^{-}$gave no host-guest species, but only $\left[\mathrm{V}_{5} \mathrm{O}_{14}\right]^{3-[16]}$ was obtained with $70 \%$ yield based on vanadium. The order of the yields of the products corresponded with the order of the halides, $\mathrm{F}^{-}, \mathrm{Cl}^{-}$, and $\mathrm{Br}^{-}$, which implies the size of the template act as a key factor for their formation, and the iodide ion may be too large to incorporate in the polyoxovanadates formed in these reactions. In the template incorporation reactions, the total charges of -4 on each polyoxovanadate were maintained. Elemental analyses of these polyoxovanadates were perfomed using thoroughly dried samples to avoid partial loss of packing molecules in the lattice, such as volatile $\mathrm{CHCl}_{3}$ or $\mathrm{CH}_{2} \mathrm{Cl}_{2}$.

\section{IR Spectroscopy}

The IR spectrum of 3 shows strong bands around $989 \mathrm{~cm}^{-1}$ that correspond to the $v\left(V=\mathrm{O}_{\text {terminal }}\right)$ stretching frequencies (Figure $\left.2 \mathrm{~b}\right)$. The $\mathrm{V}-\mathrm{O}_{\text {bridge }}$ stretching appears in the range of $500-900 \mathrm{~cm}^{-1}$. The notable differences between the lacunary complex $\mathbf{3}$ and the spherical pentadecavanadate ${ }^{[17]}\left[\mathrm{V}_{9}{ }_{9} \mathrm{~V}^{\mathrm{IV}}{ }_{6} \mathrm{O}_{36} \mathrm{Cl}\right]^{4-}$ are observed in the IR pattern of the $\mathrm{V}-\mathrm{O}_{\text {bridge }}$ stretching region. The pentadecavanadate has distinct peaks in the range of $500-750 \mathrm{~cm}^{-1}$, but the peaks in the range of $750-900 \mathrm{~cm}^{-1}$ are insignificant. The structure of the pentadecavanadate consists of $\mu^{3}-\mathrm{O}$ bridges and no $\mu^{2}$-O bridges were observed in the reduced core. The lack of $\mu^{2}-\mathrm{O}$ bridges is consistent with the weak spectrum in the $750-900 \mathrm{~cm}^{-1}$ range. Complex 3 has $\mu^{2}-\mathrm{O}$ bridges at the lacunary positions in addition to $\mu^{3}-\mathrm{O}$ bridges.

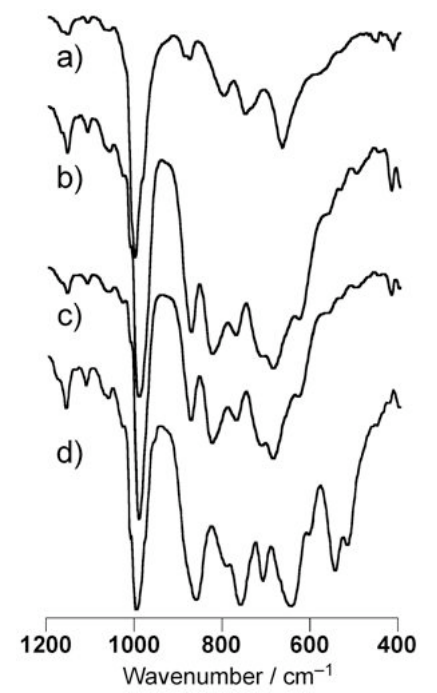

Figure 2. Infrared spectra of (a) $\left[\mathrm{V}^{\mathrm{V}}{ }_{9} \mathrm{~V}^{\mathrm{IV}}{ }_{6} \mathrm{O}_{36} \mathrm{Cl}\right]^{4-}$; (b) complex 3; (c) complex 5, and (d) $\left[\mathrm{V}_{12} \mathrm{O}_{32}\left(\mathrm{CH}_{3} \mathrm{CN}\right)\right]^{4-}(\mathbf{2})$.

Complex 2 also has $\mu^{2}-\mathrm{O}$ bridges and exhibits distinct peaks in the $750-900 \mathrm{~cm}^{-1}$ region. The peaks in the $750-900 \mathrm{~cm}^{-1}$ range are 
due to $v\left(\mathrm{~V}-\mu^{2}-\mathrm{O}\right)$ stretching frequencies. The infrared spectra of 3 and $\mathbf{5}$ are quite similar, which supports that both complexes have the same lacunary spherical frameworks with halide ion incorporation.

\section{Structures}

The ORTEP view of $\mathbf{3}$ is depicted in Figure 3 . The polyoxovanadate framework of $\mathbf{3}$ is a geometrical isomer of the precedented Klemperer dodecavanadate, and $\mathbf{3}$ has chloride inclusion with protonation at the core. It is the first example of an anion-incorporated spherical polyoxovanadate with all the vanadium atoms in $\mathrm{V}(\mathrm{V})$ oxidation state. ${ }^{[18]}$ The twelve $\mathrm{VO}_{5}$ units are joined by vertex or edge sharing to form the spherical structure. Bond valence sum (BVS) calculations suggest $\mathrm{O} 9$ and $\mathrm{O} 20$ have low BVS values of 1.35 and 1.73, respectively. ${ }^{[19]}$ All the other oxygens have BVS values in the range of 1.88-2.14. From these observations, the best estimate of the protonated site has to be on O9, which is able to interact with $\mathrm{O} 20$ through a hydrogen bond. Unfortunately, six molecules of dichloromethane were present in the lattice with relatively larger thermal motion, and we were unable to locate the positions of the protons from the Fourier map. The structure may be regarded as a lacunary counter part of the reduced pentadecavanadate, $\left[\mathrm{V}_{9}{ }_{9} \mathrm{~V}^{\mathrm{IV}}{ }_{6} \mathrm{O}_{36} \mathrm{Cl}\right]^{4} \cdot{ }^{[17]}$ The addition of two missing vanadium groups of $\mathrm{VO}$ and $\mathrm{V}_{2} \mathrm{O}_{3}$ units to 3 reconstructs the framework of the pentadecavanadate as shown in Figure 4. The first lacunary group is the $\mathrm{V}=\mathrm{O}$ unit at the site surrounded by four oxygens $(\mathrm{O} 9, \mathrm{O} 20, \mathrm{O} 8$ and $\mathrm{O} 19)$ and the coordination of these four oxygens to the $\mathrm{V}=\mathrm{O}$ group rebuilds the $\mathrm{VO}_{5}$ unit at the lacunary position. The second lacunary group is the $\mathrm{V}_{2} \mathrm{O}_{3}$ unit at the site surrounded by six oxygens $(\mathrm{O} 5, \mathrm{O} 10, \mathrm{O} 11$, $\mathrm{O} 23$, O16, and $\mathrm{O} 15)$ and also the coordination of these oxygens retrieve the complete spherical framework of the pentadecavanadate instead of the lacunary structure. The range of $\mathrm{V}=\mathrm{O}$ terminal distances of $\mathbf{3}$ is 1.579(4)-1.612(4) $\AA$ and the distances of $\mathrm{V}-\mathrm{O}_{\text {bridge }}$ are in the range of 1.708(4)-2.060(4) $\AA$. The $\mathrm{V}=\mathrm{O}$ terminal distances of the precedented pentadecavanadate are in the range of 1.578(8)-1.607(10) $\AA$ and the distances of $\mathrm{V}-\mathrm{O}_{\text {bridge }}$ are in the range of $1.823(5)-2.060(8) \AA$.

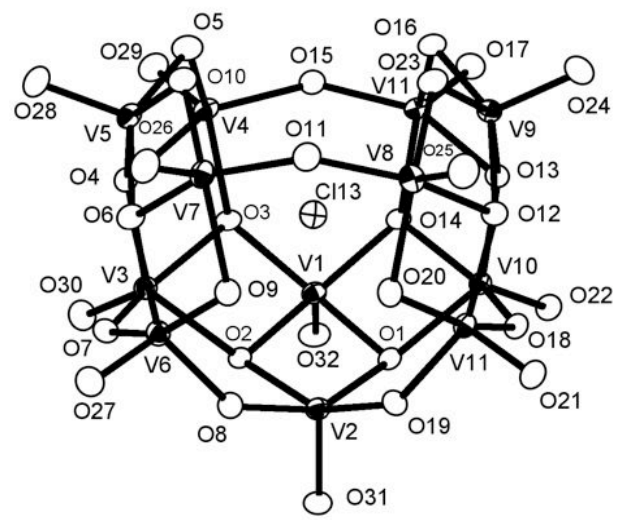

Figure 3. ORTEP view of compound 3.

Although some of the $\mathrm{V}-\mathrm{O}$ bridging distances of $\mathbf{3}$ are shorter than the precedented pentadecavanadate, the overall cluster size of the lacunary $\mathbf{3}$ is very close to that of the precedented pentadecavanadate. The structural differences between the lacunary complex $\mathbf{3}$ and the pentadecavanadate are observed in the difference of the $\mathrm{V} \cdots \cdot \mathrm{Cl}$ distances. The $\mathrm{V} \cdots \mathrm{Cl}$ distances of $\mathbf{3}$ are in a narrow range of $3.22-3.49 \AA$, while the distances of the pentadecavanadate are distributed in the range of 3.07-3.71 $\AA$. Observation of the less variation in the distances of $\mathbf{3}$ is due to the spherical framework with all the vanadium atoms in the same V(V) oxidation state. The shorter $\mathrm{V} \cdots \mathrm{Cl}$ distances in $\mathbf{3}$ indicate that the negative-negative charge repulsions are compensated in the highest oxidation core of 3 . The large variation of the $\mathrm{V} \cdots \cdot \mathrm{Cl}$ distances in the reduced pentadecavanadate are due to the existence of shorter $\mathrm{V}(\mathrm{V}){ }^{\cdots} \mathrm{Cl}$ distances and longer $\mathrm{V}(\mathrm{IV}) \cdots \mathrm{Cl}$ distances despite the charge delocalization in the spherical core. It is noted that the six dichloromethane molecules are in close contact with the cluster framework. The dichloromethane protons are pointing in the direction of the cluster oxo surface. Unfortunately, the crystals of the bromide-incorporated complex 5 were not suitable for X-ray analysis, although the spectroscopic and analytical data are in good agreement with the formation of the same core of $\mathbf{3}$, especially in the IR spectroscopy. a)

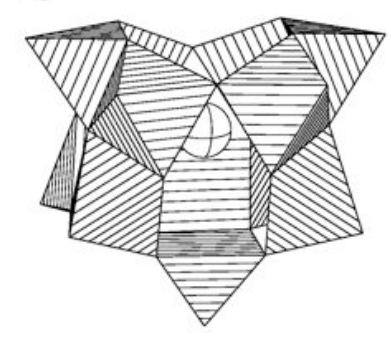

b)

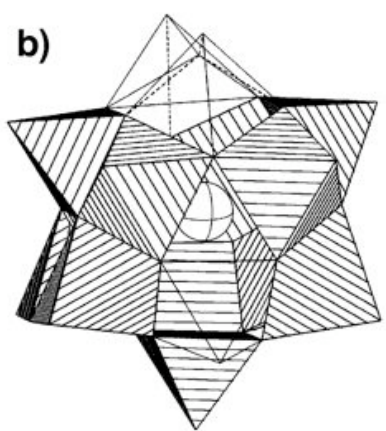

Figure 4. Polyhedral views showing the lacunary positions of 3 . The $\mathrm{VO}_{5}$ units are represented by striped polyhedrons: Polyhedral representation of a) 3 and b) $\left[\mathrm{V}_{9}^{\mathrm{V}} \mathrm{V}^{\mathrm{IV}}{ }_{6} \mathrm{O}_{36} \mathrm{Cl}\right]^{4-}$. The structure of $\mathbf{3}$ is considered to be a trilacunary-type pentadecavanadate. The $\mathrm{VO}$ unit at front and the $\mathrm{V}_{2} \mathrm{O}_{3}$ unit on the top are missing in 3. The lacunary units corresponding to the structure of $\mathbf{3}$ are represented by the frame polyhedrons in b).

The fluoride-incoporated complex $\mathbf{4}$ has a mono-lacunary framework, and the ORTEP view is shown in Figure 5. The asymmetric unit of $\mathbf{4}$ is related by a center of symmetry, and it can be considered as a layered polyoxovanadate.

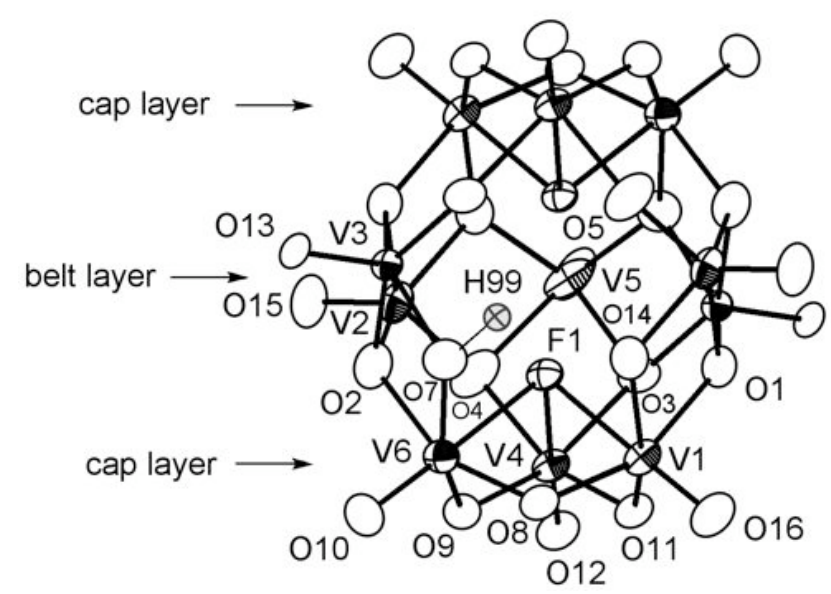

Figure 5. ORTEP view of compound 4. The anion is shown to represent the non-disordered framework by removal of the $\left(\mathrm{V} 5^{*}\right)=\mathrm{O}$ group from the belt layer. The lacunary positions are disordered over four positions at V3, V3 ${ }^{*}$, V5 and $V 5^{*}$ with total occupancy of three. 
The cluster consists of five $\mathrm{VO}_{5}$ units on the belt layer and two capping groups of three $\mathrm{VO}_{5} \mathrm{~F}$ units sandwiched the belt layer. Each unit is edge-shared to form the layered structure. The $\mu^{3}-\mathrm{F}$ bridge connects V1, V4 and V6 octahedrons. The structure of 4 resembles that of $\left[\mathrm{H}_{6} \mathrm{~V}_{2}{ }_{2} \mathrm{~V}^{\mathrm{IV}}{ }_{10} \mathrm{O}_{30} \mathrm{~F}_{2}\right]^{6-}$ reported by Müller's group. ${ }^{[20]}$ The removal of one $\mathrm{VO}$ unit from $\left[\mathrm{H}_{6} \mathrm{~V}_{2}^{\mathrm{V}}{ }_{2} \mathrm{~V}^{\mathrm{IV}}{ }_{10} \mathrm{O}_{30} \mathrm{~F}_{2}\right]^{6-}$ gives the structure of $\mathbf{4}$. The lacunary position of the $\mathrm{VO}$ unit of 4 is disordered over four positions at $\mathrm{V} 3, \mathrm{~V} 5, \mathrm{~V} 3 *$ and $\mathrm{V} 5 *$. The total occupancy of the VO units from V3 and V5 is 3, and this corresponds to having three $\mathrm{V}=\mathrm{O}$ groups out of the four positions when the symmetrically related positions are taken into account. The $\mathrm{V}=\mathrm{O}$ group from $\mathrm{V} 2$ has full occupancy and it gives two symmetrically related $\mathrm{V}=\mathrm{O}$ groups at the belt layer. Thus, the belt layer has five $\mathrm{V}=\mathrm{O}$ groups out from the six positions of $\mathrm{V} 2, \mathrm{~V} 3$ and $\mathrm{V} 5$ with the symmetrically related groups. The $\mathrm{V}=\mathrm{O}, \mathrm{V}-\mathrm{O}_{\text {bridge, }}$, and $\mathrm{V}-\mathrm{F}$ distances of $\mathbf{4}$ are in the range of 1.588(4)-1.602(4), 1.802(3)-2.098(5), and 2.203(3)-2.221(3) A, respectively. The protonation sites were estimated from BVS calculations. The BVS values of $\mathrm{O} 3, \mathrm{O} 4, \mathrm{O} 7$ and $\mathrm{O} 14$ are 1.57, 1.54, 1.25 and 1.28, respectively. The BVS values of the remaining oxygens are in the range of 1.85-2.11. Thus, the protonation site is estimated at $\mathrm{O} 7$ or $\mathrm{O} 14$ and hydrogen bonded to $\mathrm{O}^{*}$ or $\mathrm{O} 4{ }^{*}$, respectively. One of the protons, $\mathrm{H} 99$ was found on the Fourier map.

\section{NMR studies}

Despite the high sensitivities of ${ }^{51} \mathrm{~V}$ NMR spectroscopy, there are only a small number of isolated isopolyoxovanadates, and the lacunary type polyoxovanadates provide good examples for the chemical shifts. ${ }^{51} \mathrm{~V}$ NMR spectra of $\mathbf{3}$ were recorded at $-25,25$, and $75^{\circ} \mathrm{C}$, and are given in Figure 6. The NMR spectrum at $75^{\circ} \mathrm{C}$ reveals seven well-resolved lines at $-536,-558,-560,-567,-569$, -571 and $-627 \mathrm{ppm}$ with a relative intensity ratio of $2: 2: 2: 2: 1: 1: 2$. At $-25^{\circ} \mathrm{C}$, these signals are merged into four signals at $-544,-569$, -578 and $-632 \mathrm{ppm}$ with an intensity ratio of 1:4:5:2 with the higher-field shift. The signals are broader at low temperature and sharper at high temperature. The temperature dependency of the line widths was reversible. The intensity ratio and the number of signals are consistent with the geometry observed in the crystal structure. Although the complexity of structures with similar chemical environments prevents unambiguous assignments, the distinct signals matched to the chemical environments provides confident evidence regarding the host-guest structure in the solution, as is also supported by the 2D COSY NMR spectra with temporal assignments (see Supporting Information). For the full assignments of these signals, synthesis of the derivatives or substituted complexes is required by taking advantages of the lacunary structure. No apparent sign of dynamic behavior was observed from the variable temperature observations. However, small signals arose around $600 \mathrm{ppm}$ at $75{ }^{\circ} \mathrm{C}$ did not disappear when the temperature was reduced to room temperature, and these signals are most likely due to decomposed materials that are yet unidentified. (Figure S1) As the temperature increases, the line widths decreased due to the quadrapole effects of the ${ }^{51} \mathrm{~V}$ nuclei. ${ }^{[21]}$ From the structural points, complex $\mathbf{3}$ is a geometrical isomer of $\mathbf{2}$, and similar chemical shifts between $\mathbf{2}$ and $\mathbf{3}$ are expected when the chloride incorporation is not taken into account. However the signal of $\mathbf{3}$ in the range of the chemical shifts of complex $\mathbf{2}$ was observed only at $-627 \mathrm{ppm}$. The remaining six signals were significantly down-field shifted. These down-field shifts are indicative of chloride inclusion in the cluster, and are consistent with the shift of $\left[\mathrm{VOX}_{4}\right]^{-}$, which was also down-field shifted when $\mathrm{X}^{-}$was substituted for $\mathrm{Cl}^{-}{ }^{-22]}$ Bromide complex 5 in acetonitrile was susceptible to decomposition, even at room temperature. However, as the signals from decomposition products increased, the chemical shifts of the main signals could be identified and were almost identical to complex 3 . This is consistent with the formation of the bromide inclusion with the same structure as $\mathbf{3}$ The ${ }^{35} \mathrm{Cl}$ NMR signal of 2 was recorded in $\mathrm{CD}_{3} \mathrm{CN}$ at room temperature. A singlet at $162 \mathrm{ppm}\left(\Delta v_{1 / 2}=1400 \mathrm{~Hz}\right)$ was observed and the line width was significantly sharper when compared with typical compounds such as that from $\mathrm{CH}_{2} \mathrm{Cl}_{2}(7500 \mathrm{~Hz})$. The relatively sharp signal reflects the spherical environments of the chloride anion in the polyoxovanadate host. The ${ }^{35} \mathrm{Cl}$ NMR signal of compound 3 was observed even three days after sampling, with a new accompanying signal at $91 \mathrm{ppm}$, which indicated minor decomposition.
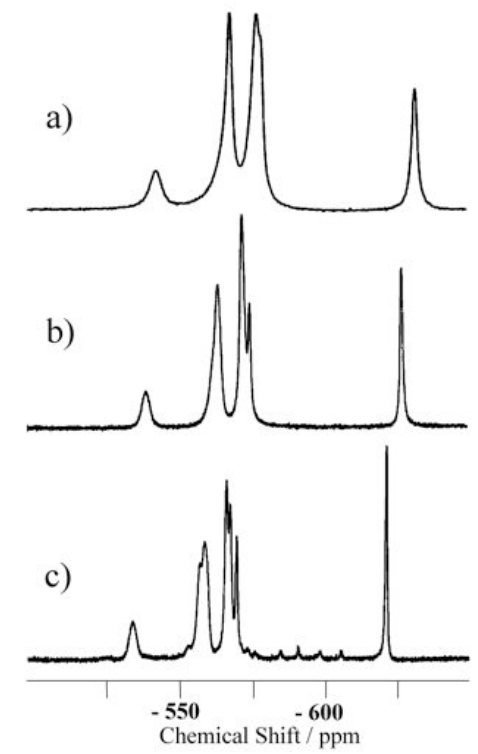

Figure 6. ${ }^{51} \mathrm{~V}$ NMR spectra of 3 in $\mathrm{CD}_{3} \mathrm{CN}$ : at (a) $-25^{\circ} \mathrm{C}$; (b) $25^{\circ} \mathrm{C}$; and (c) $75^{\circ} \mathrm{C}$

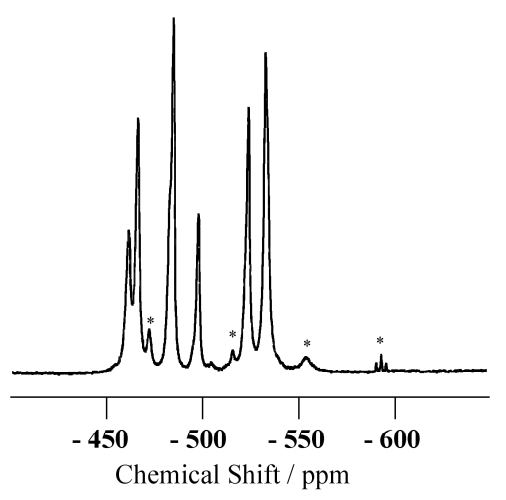

Figure 7. ${ }^{51} \mathrm{~V}$ NMR spectrum of 4 at $-25^{\circ} \mathrm{C}$ in $\mathrm{CD}_{3} \mathrm{CN}$. The signals designated by $*$ are from decomposition products.

The ${ }^{51} \mathrm{~V}$ NMR spectrum of 4 is shown in Figure 7. At $25^{\circ} \mathrm{C}$, complex 4 showed six signals at $-462,-467,-485,-499,-525$ and $-533 \mathrm{ppm}$ with an intensity ratio of 1:2:3:1:2:2. The number of signals and the intensity ratio was consistent with the geometry of the mono-lacunary structure. The compound was not stable at $75^{\circ} \mathrm{C}$, and showed a substantial decrease in the intensity of the six signals and an increase in intensity of new signals at $-474,-518$ and $-556 \mathrm{ppm}$, due to the formation of unidentified decomposition products. Prolonged heating at $75^{\circ} \mathrm{C}$ increased the distinct tripletlike signals at $-586,-592$ and $-600 \mathrm{ppm}$; the chemical shifts and 
the pattern of the signals became comparable to complex 2. The down-field shifts of these signals from that of $\mathbf{2}$ may suggest the formation of new fluoride-included dodecavanadate, $\left[\mathrm{V}_{12} \mathrm{O}_{32} \mathrm{~F}\right]^{3-}$ with the same framework as $\mathbf{2}$; however, isolation of the products was not successful.

\section{Interconversion reaction of the cages}

Template exchange reactions have been studied by Yamase's group using the V(IV) spherical polyoxovanadate, $\left[\mathrm{V}_{18} \mathrm{O}_{42}\left(\mathrm{H}_{2} \mathrm{O}\right)\right]^{12-} \cdot{ }^{[23]}$ Air oxidation reactions of the compound with template anions led to the isolation of various types of incorporated complexes with different ratio of reduced sites. In our case, reactions with the halide templates revealed interconversion reactions of the dodecavanadate framework with the highest oxidation state vanadium atoms. A summary of the interconversion reactions is shown in Scheme 1.

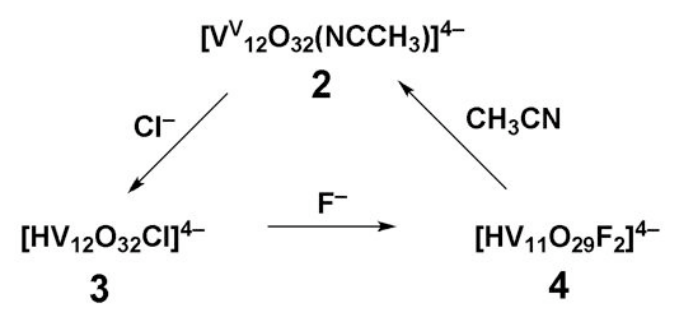

Scheme 1. Interconversion reactions of the $\mathrm{V}^{\mathrm{V}}$ open cage lacunary polyoxovanadates.

First, dodecavanadate $\mathbf{2}$ was reacted with chloride anion. Addition of $n-\mathrm{Bu}_{4} \mathrm{NCl}$ to an acetonitrile solution of $\mathbf{2}$ was heated at $60{ }^{\circ} \mathrm{C}$ and the brown solution gradually turned deep red. After recrystallization, high-quality crystals of $\mathbf{3}$ were obtained. The nucleophilic chloride was incorporated into the bowl-type dodecavanadate and the structure was transformed into 3 . The protonation of $\mathbf{3}$ suggested the reaction was not simply a guest exchange, but an acid promoted reaction. The reverse reaction, that of $\mathbf{3}$ with acetonitrile, was not observed from the ${ }^{51} \mathrm{~V}$ NMR. The pattern of the ${ }^{51} \mathrm{~V}$ NMR spectrum of $\mathbf{3}$ in acetonitrile solution was not affected by the increase in temperature except the line width, and the formation of $\mathbf{2}$ was not observed from NMR studies. The results suggest that the rigid framework of the chloride compound $\mathbf{3}$ is stable in acetonitrile without dissociation of the chloride, as expected from the lacunary geometry of $\mathbf{3}$, which is an isomer of bowl-shaped 2. The second attempted reaction was that of the chloride compound $\mathbf{3}$ with fluoride anions. When compound 3 was heated with an excess amount of $n-\mathrm{Bu}_{4} \mathrm{NF} \cdot 3 \mathrm{H}_{2} \mathrm{O}$ in dichloromethane, the color of the solution was changed from deep red to orange, and crystals of compound 4 were produced. The electronegative and nucleophilic fluoride anion promoted the conversion of the tri-lacunary dodecavanadate into the layered undecavanadate with the inclusion of two fluoride ions. On the contrary, no reaction was observed for $\mathbf{4}$ with an excess amount of chloride anions according to the ${ }^{51} \mathrm{~V}$ NMR spectra. The ${ }^{51} \mathrm{~V}$ NMR spectrum of 4 showed six signals consistent with the geometry revealed by structural analysis; however the complex was gradually decomposed in acetonitrile. In addition to these signals, new signals were observed at $-474,-518$ and $-556 \mathrm{ppm}$ along with triplet-like signals at $-600 \mathrm{ppm}$. At $75{ }^{\circ} \mathrm{C}$, the intensities of the signals of 4 were significantly decreased and the triplet-like signals increased at $-593,-600$, and $-608 \mathrm{ppm}$. The isolation of 2 from an acetonitrile solution of $\mathbf{4}$ was possible after recrystallization. The fluorides-incorporated complex 4 was unstable, as observed from the ${ }^{51} \mathrm{~V}$ NMR at $75^{\circ} \mathrm{C}$, and polar solvents promoted decomposition reactions. The reaction of 2 with $n-\mathrm{Bu}_{4} \mathrm{NF} \cdot 3 \mathrm{H}_{2} \mathrm{O}$ was unable to yield 4 , and the product formed was confirmed as $\left[\mathrm{V}_{5} \mathrm{O}_{14}\right]^{3-}$ from ${ }^{51} \mathrm{~V}$ NMR spectroscopy.

\section{Conclusions}

Guest incorporation reactions of lacunary polyoxovanadates were demonstrated by oxidation reactions of the reduced decavanadate (1). Two types of polyoxovanadates with vanadium atoms in the $\mathrm{V}(\mathrm{V})$ oxidation state were isolated and characterized. The polyoxovanadate framework of the fluoride complex (4) was a layered mono lacunary undecavandate, and the chloride complex (3) was a tri-lacunary dodecavanadate. Oxidation reaction without the halide anion in acetonitrile resulted in the improved synthesis of the bowl-type dodecavanadate (2). Reactivity studies of these open cage polyoxovanadates revealed interconversion reactions between the species. Further investigation of these species, such as the addition of hetero metals, by taking advantage of the lacunary structure, will lead to the development of new lacunary polyoxovanadate chemistries. We assert these new $\mathrm{V}(\mathrm{V})$ polyoxovanadate derivatives will provide further understanding of the host-guest chemistry of polyoxovanadates through ${ }^{51} \mathrm{~V}$ NMR studies, of which only limited number of compounds, typically metavanadates and decavanadates, are presently known.

\section{Experimental Section}

Measurements: IR spectra were measured in mineral oil or $\mathrm{KBr}$ pellets using a Horiba FT-720 IR spectrometer. NMR samples were measured in $\mathrm{CD}_{3} \mathrm{CN}$ solution at $25{ }^{\circ} \mathrm{C}$. ${ }^{51} \mathrm{~V}$ NMR spectra were recorded on a JEOL JNM-LA400 at $105.04 \mathrm{MHz}$. Chemical shifts were externally referenced to pure $\mathrm{VOCl}_{3}(\delta=0 \mathrm{ppm}) .{ }^{35} \mathrm{Cl} \mathrm{NMR}$ spectra were recorded on a JEOL JNM-LA400 at $40.25 \mathrm{MHz}$. Chemical shifts were externally referenced to saturated $\mathrm{KCl}$ aqueous solution $(\delta=0 \mathrm{ppm})$.

Synthesis: All reagents were reagent grade and used without further purification. Solvents were dried and distilled, then stored under nitrogen. 1 was synthesized using modified methods of published procedures ${ }^{[11]}$ (see Supporting Information) and purity was confirmed by IR spectroscopy and elemental analysis. Elemental analyses of $\mathrm{C}, \mathrm{H}$ and $\mathrm{N}$ were performed by the Research Institute for Instrumental Analysis at Kanazawa University. Elemental analyses of $\mathrm{F}, \mathrm{Cl}$ and $\mathrm{Br}$ were performed by the Center for Organic Elemental Microanalysis Laboratory at Kyoto University.

Improved synthesis of $\left(\boldsymbol{n}-\mathrm{Bu}_{4} \mathbf{N}\right)_{4}\left[\mathbf{V}^{\mathbf{v}}{ }_{12} \mathbf{O}_{32}\left(\mathrm{CH}_{3} \mathbf{C N}\right)\right]$ (2): $30 \%$ hydrogen peroxide (284 mg) was added dropwise to the violet solution of 1 (948 $\mathrm{mg}$, $0.50 \mathrm{mmol})$ in acetonitrile $(10 \mathrm{~mL})$. The resulting brown solution was stirred for $1 \mathrm{~h}$ at room temperature and diethylether $(40 \mathrm{~mL})$ was added to yield a brown powder. Yield $798 \mathrm{mg}(90 \%$ based on V). The solid obtained was sufficiently pure for the subsequent synthesis. X-ray analysis quality crystals was obtained by recrystallization from acetonitrile and ethylacetate. IR $\left(\mathrm{KBr}, 500-1000 \mathrm{~cm}^{-1}\right): v=521(\mathrm{~s}), 550(\mathrm{~s}), 608(\mathrm{sh})$, 646(vs), 710(s), 760(vs), 791(sh), 860(vs), 993(vs) cm ${ }^{-1} .{ }^{51} \mathrm{~V}$ NMR (105.04 $\left.\mathrm{MHz}, \mathrm{CD}_{3} \mathrm{CN}, 25{ }^{\circ} \mathrm{C}, \mathrm{VOCl}_{3}\right): \delta=-593(4 \mathrm{~V}),-600(4 \mathrm{~V}),-608(4 \mathrm{~V}) \mathrm{ppm}$. $\left(n-\mathrm{Bu}_{4} \mathrm{~N}\right)_{4}\left[\mathrm{~V}_{12} \mathrm{O}_{32}\right](2093.2)$ calcd. C 36.72, H 6.93, N 2.68; found C 36.38, H 6.99, N 2.69.

$\left(\boldsymbol{n}-\mathrm{Bu}_{4} \mathbf{N}\right)_{4}\left[\mathbf{H V}^{\mathrm{v}}{ }_{12} \mathbf{O}_{32}(\mathrm{Cl})\right](3)$ : Compound $\mathbf{1}(948 \mathrm{mg}, 0.50 \mathrm{mmol})$ and tetra$n$-butylammonium chloride (556 $\mathrm{mg}, 2.0 \mathrm{mmol}$ ) was dissolved in dichloromethane $(30 \mathrm{~mL})$. tert-Butyl hydroperoxide $(120 \mathrm{mg}, 1.0 \mathrm{mmol})$ was added dropwise to the mixture and the purple solution gradually tuned intense red. The solution was stirred for $30 \mathrm{~min}$ and then cooled in a 
refrigerator. Red crystals were formed over 2 days. Yield $313 \mathrm{mg}(35 \%$ based on V). IR (KBr, 500-1000 $\left.\mathrm{cm}^{-1}\right): v=528(\mathrm{w}), 571(\mathrm{sh}), 629(\mathrm{~m})$, 669(sh), 687(s), 714(s), 779(m), 824(s), 874(m), 989(vs) $\mathrm{cm}^{-1} .{ }^{51} \mathrm{~V}$ NMR $\left(105.04 \mathrm{MHz}, \mathrm{CD}_{3} \mathrm{CN}, 25^{\circ} \mathrm{C}, \mathrm{VOCl}_{3}\right): \delta=-540(1 \mathrm{~V}),-565(4 \mathrm{~V}),-573(5 \mathrm{~V})$, $-626(2 \mathrm{~V}) \mathrm{ppm} .{ }^{35} \mathrm{Cl} \mathrm{NMR}\left(40.25 \mathrm{MHz}, \mathrm{CD}_{3} \mathrm{CN}, 25^{\circ} \mathrm{C}\right.$, saturated $\mathrm{KCl}$ aqueous solution $): \quad \delta=+162\left(\Delta v_{1 / 2}=1400 \mathrm{~Hz}\right)$ ppm. $(n-$ $\left.\mathrm{Bu}_{4} \mathrm{~N}\right)_{4}\left[\mathrm{HV}_{12} \mathrm{O}_{32}(\mathrm{Cl})\right]$ (2129.6) calcd. C 36.10, H 6.86, N 2.63, Cl 1.66; found $\mathrm{C} 36.25 \mathrm{H} 6.91, \mathrm{~N} 2.64, \mathrm{Cl} 1.63$.

$\left(\boldsymbol{n}-\mathrm{Bu}_{4} \mathrm{~N}\right)_{4}\left[\mathbf{H V}^{\mathrm{V}}{ }_{11} \mathbf{O}_{29} \mathbf{F}_{2}\right]$ (4): Compound $\mathbf{1}(379 \mathrm{mg}, 0.20 \mathrm{mmol})$ and tetra$n$-butylammonium floride $(315 \mathrm{mg}, 1.0 \mathrm{mmol})$ were dissolved in dichloromethane $(20 \mathrm{~mL})$. tert-Butyl hydroperoxide $(60 \mathrm{mg}, 0.5 \mathrm{mmol})$ was carefully added dropwise to the mixture and the purple solution gradually turned intense red. The solution was dried over anhydrous magnesium sulfate and then concentrated by heating to $10 \mathrm{~mL}$ of solution, to which chloroform $(20 \mathrm{~mL})$ was added. Red crystals were obtained after 2 days. Yield $200 \mathrm{mg}\left(54 \%\right.$ based on V). IR (KBr, 500-1000 $\left.\mathrm{cm}^{-1}\right): v=$ 625(m), 660(m), 739(m), 800(s), 854(m), 876(m), 966(s), 982(vs), 991(vs) $\mathrm{cm}^{-1} .{ }^{51} \mathrm{~V}$ NMR $\left(105.04 \mathrm{MHz}, \mathrm{CD}_{3} \mathrm{CN}, 25^{\circ} \mathrm{C}, \mathrm{VOCl}_{3}\right): \delta=-462(1 \mathrm{~V}),-$ $467(1 \mathrm{~V}),-485(3 \mathrm{~V}),-499(1 \mathrm{~V}),-525(2 \mathrm{~V}),-533(3 \mathrm{~V}) \mathrm{ppm} . \quad{ }^{19} \mathrm{~F}$ NMR $\left(377.44 \mathrm{MHz}, \mathrm{CD}_{3} \mathrm{CN}, 25^{\circ} \mathrm{C}, n-\mathrm{Bu}_{4} \mathrm{NPF}_{6}\right): \delta=-72\left(\mathrm{~d},{ }^{1} J_{\mathrm{F}-\mathrm{V}}=55 \mathrm{~Hz}\right),-77(\mathrm{~d}$, $\left.{ }^{1} J_{\mathrm{F}-\mathrm{V}}=58 \mathrm{~Hz}\right) \mathrm{ppm} .\left(n-\mathrm{Bu}_{4} \mathrm{~N}\right)_{4}\left[\mathrm{HV}_{11} \mathrm{O}_{29} \mathrm{~F}_{2}\right](2033.2)$ calcd. C $37.81, \mathrm{H} 7.19$, N 2.76, F 1.87; found C 37.31 H 7.14, N 2.74, F 1.73 .

$\left(\boldsymbol{n}-\mathrm{Bu}_{4} \mathrm{~N}\right)_{4}\left[\mathrm{HV}^{\mathrm{V}}{ }_{12} \mathrm{O}_{32}(\mathrm{Br})\right]$ (5): Compound $\mathbf{1}(379 \mathrm{mg}, 0.20 \mathrm{mmol})$ and tetra- $n$-butylammonium bromide $(322 \mathrm{mg}, 1.0 \mathrm{mmol})$ were dissolved in dichloromethane $(20 \mathrm{~mL})$. tert-Butyl hydroperoxide $(60 \mathrm{mg}, 0.5 \mathrm{mmol})$ was added dropwise to the mixture and the purple solution turned intense red. The solution was stirred for $30 \mathrm{~min}$ and cooled in a refrigerator. Both red crystals and crystals of decavanadates $\left[\mathrm{H}_{3} \mathrm{~V}_{10} \mathrm{O}_{28}\right]^{3-}$ were formed together after 2 day. The mixture of crystals was placed in dichloromethane solution with the addition of tetra- $n$-butylammonium bromide ( $64 \mathrm{mg}, 0.20 \mathrm{mmol}$ ). Under these condition, only the red crystal of 5 was dissolved in the solution, and the undissolved decavanadate was filtered out. Red crystals of 5 were obtained. Yield $134 \mathrm{mg}$ (15\% based on V). IR ( $\left.\mathrm{KBr}, 500-1000 \mathrm{~cm}^{-1}\right): v=501(\mathrm{w}), 536(\mathrm{sh}), 629(\mathrm{~m}), 688(\mathrm{~s}), 712(\mathrm{~s})$, $771(\mathrm{~m}), 825(\mathrm{~s}), 872(\mathrm{~m}), 991(\mathrm{vs}) \mathrm{cm}^{-1} .{ }^{51} \mathrm{~V}$ NMR $\left(105.04 \mathrm{MHz}, \mathrm{CD}_{3} \mathrm{CN}\right.$, $\left.25^{\circ} \mathrm{C}, \mathrm{VOCl}_{3}\right): \delta=-540(1 \mathrm{~V}),-565(4 \mathrm{~V}),-573(5 \mathrm{~V}),-627(2 \mathrm{~V}) \mathrm{ppm} . \quad(n-$ $\left.\mathrm{Bu}_{4} \mathrm{~N}\right)_{4}\left[\mathrm{HV}_{12} \mathrm{O}_{32}(\mathrm{Br})\right]$ (2174.1) calcd. C 35.36, H 6.72, N 2.58, Br 3.68; found $\mathrm{C} 35.72 \mathrm{H} 6.87, \mathrm{~N} 2.67, \mathrm{Br} 3.85$.

X-ray Crystallography: Single crystal structure analyses were performed at $-150{ }^{\circ} \mathrm{C}$ using a Rigaku/MSC Mercury diffractometer with graphite monochromated Mo K $\alpha$ radiation $(\lambda=0.71070 \AA)$ and with $0.5^{\circ} \omega$-scans at $0^{\circ}$ and $90^{\circ}$ in $\phi$. The crystal data are summarized in Table 1.

Data were collected and processed using the CrystalClear program (ver 1.3.5, Rigaku) ${ }^{[24]}$. Numerical absorption corrections were applied using CrystalClear and corrections for Lorenz and polarization effects were performed. The structures were solved by direct methods (SHELXS-86). Non-hydrogen atoms were refined anisotropically. Hydrogen atoms were not included in the refinement of $\mathbf{3}$ due to the larger thermal motion of tetra- $n$-butylammonium salts and dichloromethane. Hydrogen atoms of 4 were included but not refined. The SHELX-97 $\operatorname{program}^{[25]}$ was used for full-matrix least-squares refinements.

CCDC-737788 (for 3) and -737789 (for 4) contain the supplementary crystallographic data for this paper. These data can be obtained free of charge from The Cambridge Crystallographic Data Centre via www.ccdc.cam.ac.uk/data_request/cif.

Table 1. Crystal data for 3 and 4.

\begin{tabular}{lll}
\hline compound & $\mathbf{3}$ & $\mathbf{4}$ \\
\hline Formula & $\left(n-\mathrm{Bu}_{4} \mathrm{~N}\right)_{4}\left[\mathrm{HV}_{12} \mathrm{O}_{32} \mathrm{Cl}\right] \cdot$ & $\left(n-\mathrm{Bu}_{4} \mathrm{~N}_{4}\left[\mathrm{HV}_{11} \mathrm{O}_{29} \mathrm{~F}_{2}\right]\right.$ \\
& $6 \mathrm{CH}_{2} \mathrm{Cl}_{2}$ & $6 \mathrm{CHCl}_{3}$ \\
Crystal system & Monoclinic & Orthorhombic \\
Space group & $P 2_{1}$ & $P b c a$ \\
$a[\AA]$ & $18.175(2)$ & $19.256(3)$ \\
$b[\AA]$ & $16.981(2)$ & $20.312(3)$ \\
$c[\AA]$ & $18.631(2)$ & $29.808(4)$ \\
$\alpha\left[^{\circ}\right]$ & 90 & 90 \\
$\beta\left[^{\circ}\right]$ & $99.635(2)$ & 90 \\
$\gamma\left[^{\circ}\right]$ & 90 & 90 \\
$V\left[\AA^{3}\right]$ & $5669(1)$ & $11658(3)$ \\
$Z$ & 2 & 4 \\
No. of data & 63857 & 13280 \\
collected & & \\
No. of data used & 27097 & 9379 \\
No. of variables & 1180 & 650 \\
$R\left(R_{w}\right)$ & $0.0528(0.1509)$ & $0.0830(0.258)$ \\
GOF & 1.248 & 1.06 \\
\hline
\end{tabular}

Supporting Information (see footnote on the first page of this article): Modified synthesis of $\left(n-\mathrm{Bu}_{4} \mathrm{~N}\right)_{4}\left[\mathrm{~V}_{10} \mathrm{O}_{26}\right]$ (1); Variable temperature ${ }^{51} \mathrm{~V}$ NMR spectra of $\mathbf{3}$ in acetonitrile- $d^{3} ;{ }^{35} \mathrm{Cl}$ NMR spectra of $\mathbf{3}$ in acetonitrile$d^{3}$; Variable temperature ${ }^{51} \mathrm{~V}$ NMR spectra of $\mathbf{4}$ in acetonitrile- $d^{3} ;{ }^{51} \mathrm{~V}-{ }^{51} \mathrm{~V}$ COSY spectrum of $\mathbf{3}$ in acetonitrile- $d^{3}$.

[1] a) A. Müller, L. Toma, H. Bögge, C. Schaffer, A. Stammler, Angew. Chem. Int. Ed. 2005, 44, 7757-7761; b) A. Müller, Y. Zhou, H Bögge, M. Schmidtmann, T. Mitra, E. T. Haupt, A. Berkle, Angew. Chem. Int. Ed. 2006, 45, 460-465; c) A. Müller, S. K. Das, P. Kögerler, H. Bögge, M. Schmidtmann, A. X. Trautwein, V. Schünemann, E. Krickemeyer, W. Preetz, Angew. Chem. Int. Ed. 2000, 39, 3413-3417; d) A. Müller, S. Q. N. Shah, H. Bögge, M. Schmidtmann, P. Kögerler, B. Hauptfleish, S. Leiding, K. Wittler, Angew. Chem. Int. Ed. 2000, 39, 1614-1616; e) A. Müller, E. Krickemeyer, H. Bögge, M. Schmidtmann, F. Peters, Angew. Chem. Int. Ed. 1998, 37, 3360-3363; f) A. Müller, M. Koop, H. Bögge, M. Schmidtmann, F. Peters, P. Kögerler, Chem. Commun. 1999, 18851886 .

[2] a) A. Müller, F. Peters, M. T. Pope, D. Gatteschi, Chem. Rev. 1998, 98, 239-271; b) A. Müller, H. Reuter, S. Dillinger, Angew. Chem. Int. Ed. 1995, 34, 2328-2361.

[3] a) M-M, Rohmer, M. Bénard, J-P. Blaudeau, J-M. Maestre, J-M. Poblet, Coord. Chem. Rev. 1998, 178-180, 1019-1049; b) J-Y. Kempf, M-M, Rohmer, J.-M. Poblet, C. Bo, M. Bénard, J. Am. Chem. Soc. 1992, 114, 1136-1146.

[4] J. M. Lehn, in Supramolecular Chemistry, VCH, Weinheim, 1995.

[5] a) V. W. Day, W. G. Klemperer, O. M. Yaghi, J. Am. Chem. Soc. 1989, 111, 5959-5961; b) G. W. Wagner, Inorg. Chem. 1991, 30, 1960-1962.

[6] a) W. G. Klemperer, T. A. Marquart, O. M. Yaghi, Mater. Chem Phys. 1991, 29, 97-104; b) N. Kawanami, T. Ozeki, A. Yagasaki, $J$ Am. Chem. Soc. 2000, 122, 1239-1240.

[7] a) M-M, Rohmer, J. Devémy, R. Wiest, M. Bénard, J. Am. Chem. Soc. 1996, 118, 13007-13014; b) M-M, Rohmer, M. Bénard, J. Am. Chem. Soc. 1994, 116, 6959-6960.

[8] a) D. Hou, K. S. Hagen, C. L. Hill. J. Am. Chem. Soc. 1992, 114 , 5864-5866; b) T. Kurata, Y. Hayashi, A. Uehara, K. Isobe, K. Chem. Lett. 2003, 1040-1041.

[9] T. Kurata, A. Uehara, Y. Hayashi, K. Isobe. Inorg. Chem. 2005, 44, 2524-2530.

[10] a) M. T. Pope in Heteropoly and Isopoly Oxometalates, SpringerVerlag, Berlin, 1983; b) J. P. Jolivet in Metal Oxide Chemistry and Synthesis, John Wiley \& Sons Ltd, England, 2000. 
[11] a) A. Bino, S. Cohen, C. Heitner-Wirguin, Inorg. Chem. 1982, 21, 429-431; b) S. M. Baxter, P. T. Wolczanski, Inorg. Chem. 1989, 28 , 3263-3264; c) C. Heitner-Wirguin, J. Selbin, Inorg. Nucl. Chem. 1968, 30, 3181-3188.

[12] a) Y. Hayashi, T. Shinguchi, T. Kurata, K. Isobe, in Vanadium: The Versatile Metal (Eds.: K. Kustin, J. C. Pessoa, D. C. Crans), Oxford University Press, 2007, Chap. 29, pp. 408-423; b) Y. Hayashi, Y. Koyama, T. Shinguchi, K. Isobe, in Vanadium Biochemistry, (Ed. M A. Alves), Research Signpost, 2007, Chap. 2, pp. 15-32; c) Y. Hayashi, N. Miyakoshi, T. Shinguchi, A. Uehara, Chem. Lett. 2001, $170-171$.

[13] A. Müller, J. Meyer, E. Krickemeyer, C. Beugholt, H. Bögge, F. Peters, M. Schmidtmann, P. Kögerler, M. J. Koop, Chem. Eur. J. 1998, 4, 1000-1006.

[14] a) A. Müller, R. Sessoli, E. Krickemeyer, H. Bögge, J. Meyer, D. Gatteschi, L. Pardi, J. Westphal, K. Hovemeier, R. Rohlfing, J. Döring, F. Hellweg, C. Beugholt, M. Schmidtmann, Inorg. Chem. 1997, 36, 5239-5250; b) A. Müller, E. Diemann, E. Krickemeyer, Naturwissenschaften. 1993, 80, 77-78; c) A. Müller, R. Rohlfing, J. Döring, M. Penk, Angew. Chem. Int. Ed. 1991, 30, 588-590; d) A. Müller, Nature. 1991, 352, 115; e) A. Müller, R. Rohlfing, J. Döring, M. Penk, Angew. Chem. Int. Ed. 1991, 30, 588-590; f) A. Müller, E. Krickemeyer, M. Penk, R. Rohlfing, A. Armatage, H. Bögge, Angew. Chem. Int. Ed. 1991, 30, 1674-1677.

[15] V. W. Day, W. G. Klemperer, D. J. Maltbie, J. Am. Chem. Soc. 1987, 109, 2991-3002.

[16] V. W. Day, W. G. Klemperer, O. M. Yaghi, J. Am. Chem. Soc. 1989 111, 4518-4519.

[17] a) P. C. H. Mitchell, Nature, 1990, 348, 15-16; b) A. Müller, M. Penk, R. Rohlfing, E. Krickemeyer, J. Döring, Angew. Chem. Int. Ed. 1990, 29, 926-927; c) A. Müller, E. Krickemeyer, M. Penk, H-J. Walberg, H. Bögge, Angew. Chem. Int. Ed. 1987, 26, 1045-1046.
[18] D. Hou, K. S. Hagen, C. L. Hill, J. Chem. Soc. Chem. Commun. 1993, 426-428.

[19] I. D. Brown, in The Chemical Bond in Inorganic Chemistry, Oxford University Press, New York, 2002.

[20] a) A. Müller, R. Rohlfing, E. Krickemeyer, H. Bögge, Angew. Chem. Int. Ed. 1993, 32, 909-912; b) A. Müller, R. Rohlfing, A. L. Barra, D. Gatteschi, Adv. Mater. 1993, 5, 915-919.

[21] J. Mason in Multinuclear NMR, Plenum Press, New York, 1987.

[22] E. A. Maatta, Inorg. Chem. 1984, 23, 2561-2563.

[23] T. Yamase, L. Yang, R. Suzuki, J. Mol. Catal. A: Chemical. 1999, $147,179-190$.

[24] CrystalClear. Version 1.3.5. Rigaku Corporation, Tokyo, Japan.

[25] G. M. Sheldrick, SHELXL-97, University of Göttingen: Göttingen, Germany, 1997. 
Entry for the Table of Contents ((Please choose one layout.))

\section{Layout 1:}

((Lacunary Polyoxovanadates))

Lacunary type polyoxovanadates with fluoride, chloride and bromide anion guests were isolated and the oxidation state of all vanadium atoms was $\mathrm{V}(\mathrm{V})$. The first $\mathrm{V}(\mathrm{V})$ spherical polyoxovanadate with lacunary units have been produced in nonpolar solvents and the interconversion reactions of the dodecavanadate frameworks were observed by the reaction with anions.

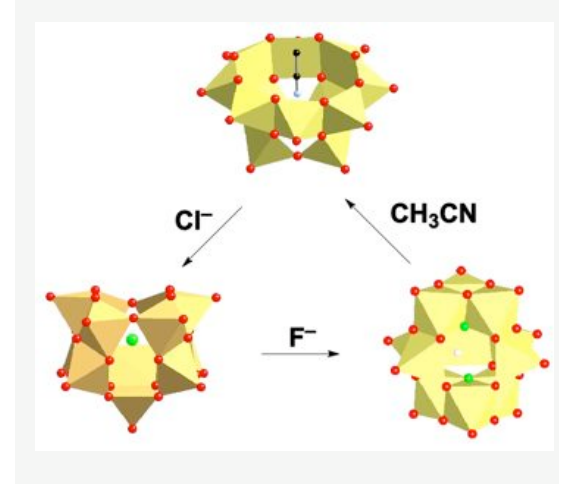

Kenji Okaya, Tetsuhiro Kobayashi, Yuki Koyama, Yoshihito Hayashi, " and Kiyoshi Isobe ....... Page No. - Page No.

Formation of V(V) Lacunary

Polyoxovanadates and Interconversion Reactions of Dodecavanadate Species

Keywords: Polyoxometalates / Vanadium / Host-guest systems / Template synthesis 


\title{
Formation of V(V) Lacunary Polyoxovanadates and Interconversion Reactions of Dodecavanadate Species
}

\author{
Kenji Okaya, Tetsuhiro Kobayashi, Yuki Koyama, Yoshihito Hayashi, ${ }^{*}$ and Kiyoshi Isobe
}

Eur. J. Inorg. Chem.

\begin{abstract}
1. Modified synthesis of $\left(n-\mathrm{Bu}_{4} \mathrm{~N}\right)_{4}\left[\mathrm{~V}_{10} \mathrm{O}_{26}\right]$ (1)
2. Figure S1. Variable temperature ${ }^{51} \mathrm{~V}$ NMR spectra of $\mathbf{3}$ in acetonitrile- $d^{3}$.

3. Figure S2. ${ }^{35} \mathrm{Cl}$ NMR spectra of $\mathbf{3}$ in acetonitrile- $d^{3}$.

4. Figure S3. Variable temperature ${ }^{51} \mathrm{~V}$ NMR spectra of 4 in acetonitrile- $d^{3}$.

5. Figure $\mathrm{S} 4 .{ }^{51} \mathrm{~V}-{ }_{-}^{51} \mathrm{~V}$ COSY spectrum of $\mathbf{3}$ in acetonitrile- $d^{3}$.
\end{abstract}

\footnotetext{
Modified synthesis of $\left(\boldsymbol{n}-\mathbf{B u}_{4} \mathbf{N}\right)_{4}\left[\mathbf{V}_{10} \mathbf{O}_{26}\right]$ (1): This modified method ${ }^{[11 b]}$ uses triethylamine instead of $n$ - $\mathrm{Bu}_{4} \mathrm{NOH}$. The suspension of $\mathrm{V}_{2} \mathrm{O}_{5}(3.62 \mathrm{~g}, 20$ $\mathrm{mmol})$ in water $(20 \mathrm{~mL})$ was heated at $60^{\circ} \mathrm{C}$, and was added triethylamine $(4.04 \mathrm{~g}, 40 \mathrm{mmol})$ dropwise to the suspention. After stirring the mixture at $60{ }^{\circ} \mathrm{C}$ for $20 \mathrm{~min}$, the solution became homogeneous under ideal condition. The heterogeneous solution might be given when the purity of vanadium pentoxide was low, and undissolved materials were filtered and excess amount of amine should be evaporated. Then acetone $(100 \mathrm{~mL})$ was added to the pale yellow homogeneous solution at room temperature. The milky white suspension was obtained, and $n-\mathrm{Bu}_{4} \mathrm{NBr}(25.8 \mathrm{~g}, 80 \mathrm{mmol})$ was added to the mixture and gave a yellow homogeneous solution. Any undissolved material was filtered off and $\mathrm{VOSO}_{4} \cdot 3 \mathrm{H}_{2} \mathrm{O}(2.17 \mathrm{~g}, 10 \mathrm{mmol})$ in water $(5 \mathrm{~mL})$ was added into the mixture with vigorous stirring. A black-purple solution was obtained and immediately precipitates were formed. After stirring for 30 min, purple powder was collected and washed with water, ethanol, then ether, and dried to yield purple powder. Yield $7.77 \mathrm{~g}, 82 \%$ based on V. It can be recrystallized from acetonitrile. IR (KBr, 500-1000 $\left.\mathrm{cm}^{-1}\right): v=530(\mathrm{~m}), 577(\mathrm{~m}), 662(\mathrm{vs}), 737(\mathrm{~m}), 756(\mathrm{~m}), 843(\mathrm{vs}), 892(\mathrm{vs}), 926(\mathrm{vs}), 957(\mathrm{vs}), 970(\mathrm{vs}), 995(\mathrm{~s}) \mathrm{cm}^{-1}$. (n$\left.\mathrm{Bu}_{4} \mathrm{~N}\right)_{4}\left[\mathrm{~V}_{10} \mathrm{O}_{26}\right] \cdot \mathrm{H}_{2} \mathrm{O}(1913.3)$ calcd. C 40.18, H 7.69, N 2.93; found C 40.24, H 7.79, N 2.92.
} 


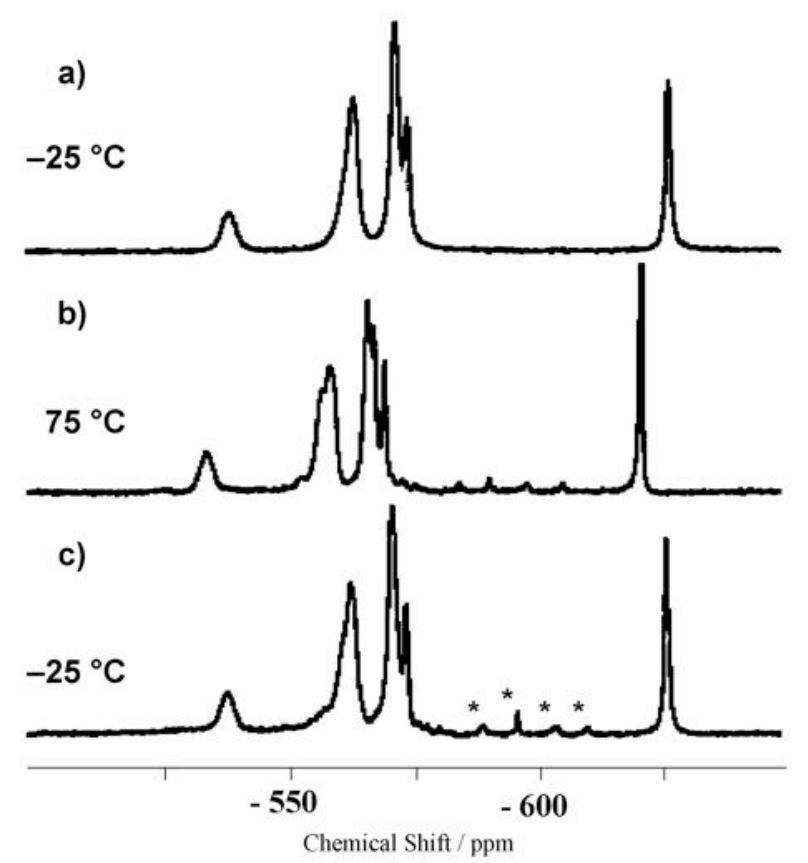

Figure S1. Variable temperature ${ }^{51} \mathrm{~V}$ NMR spectra of $\mathbf{3}$ in acetonitrile- $d^{3}$ : at (a) $-25^{\circ} \mathrm{C}$; (b) $75^{\circ} \mathrm{C}$; (c) $-25^{\circ} \mathrm{C}$ after recording data at $75{ }^{\circ} \mathrm{C}$. The line shapes of the main signals were changed reversibly with variable temperature. The line width change on the temperature are due to the quadrapole effects of ${ }^{51} \mathrm{~V}$ nuclei. New signals appeared at $75^{\circ} \mathrm{C}$ designated by * were not disappeared after cooling to $-25^{\circ} \mathrm{C}$ indicating the formation of an impurity.

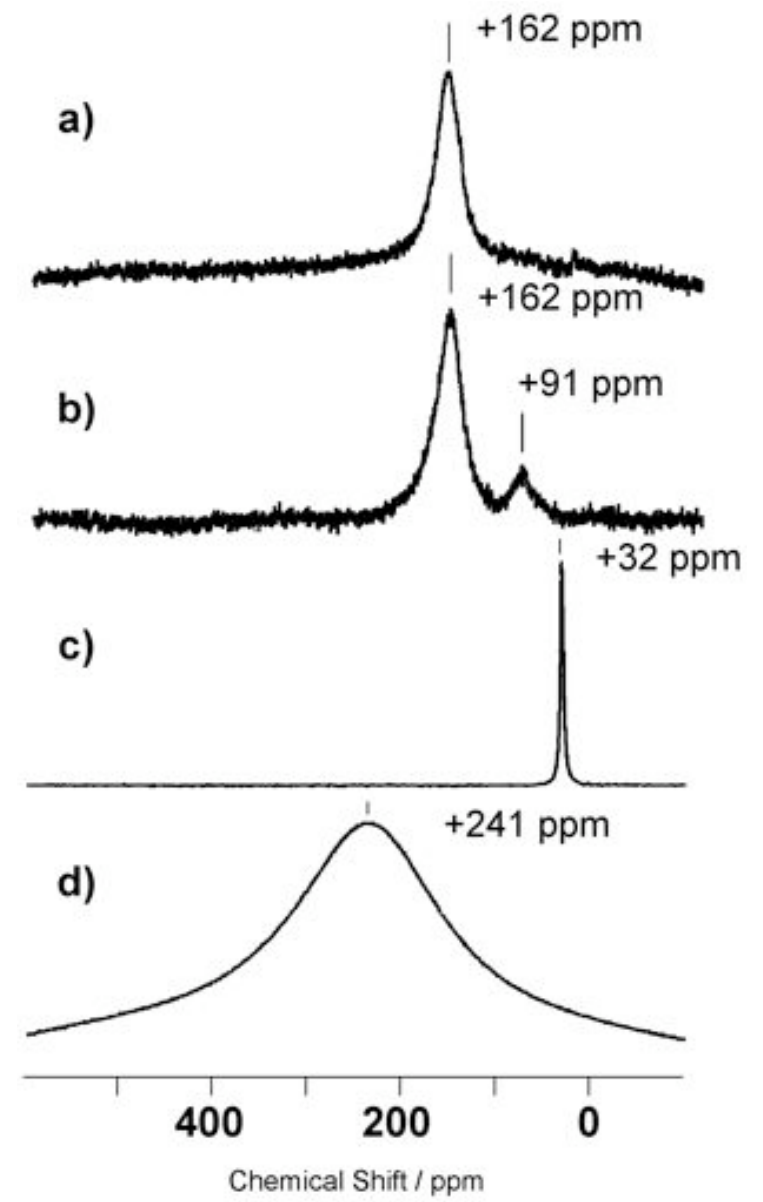

Figure S2. ${ }^{35} \mathrm{Cl}$ NMR spectra of: (a) 3 in acetonitrile- $d^{3}$; (b) 3 in acetonitrile- $d^{3}$ after 3 days of sampling; (c) $n$ - $\mathrm{Bu}_{4} \mathrm{NCl}_{\mathrm{N}}$ in $\mathrm{CH}_{3} \mathrm{CN}$; (d) $\mathrm{CH}_{2} \mathrm{Cl}_{2}$. The ${ }^{35} \mathrm{Cl} \mathrm{NMR}$ signal at $162 \mathrm{ppm}$ was observed even 3 days after sampling in acetonitrile- $d^{3}$ along with a new signal at $+91 \mathrm{ppm}$. 

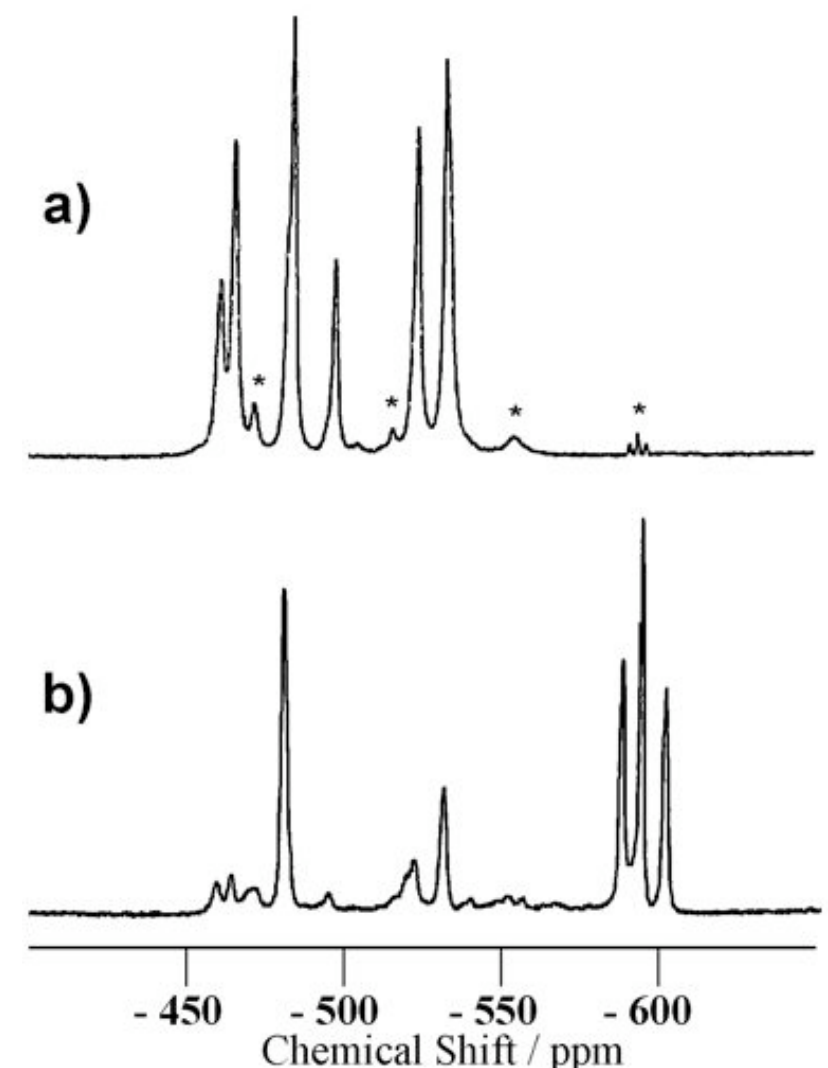

Figure S3. Variable temperature ${ }^{51} \mathrm{~V}$ NMR spectra of $\mathbf{4}$ in acetonitrile- $d^{3}$ : at (a) $25^{\circ} \mathrm{C}$; (b) $75^{\circ} \mathrm{C}$. Complex $\mathbf{4}$ was not stable at $75^{\circ} \mathrm{C}$ in acetonitrile- $d^{3}$ as shown in this variable temperature study. Even at the room temperature, minor peaks designated by $*$ due to the decomposed products were observed in addition to the peaks of 4 . 

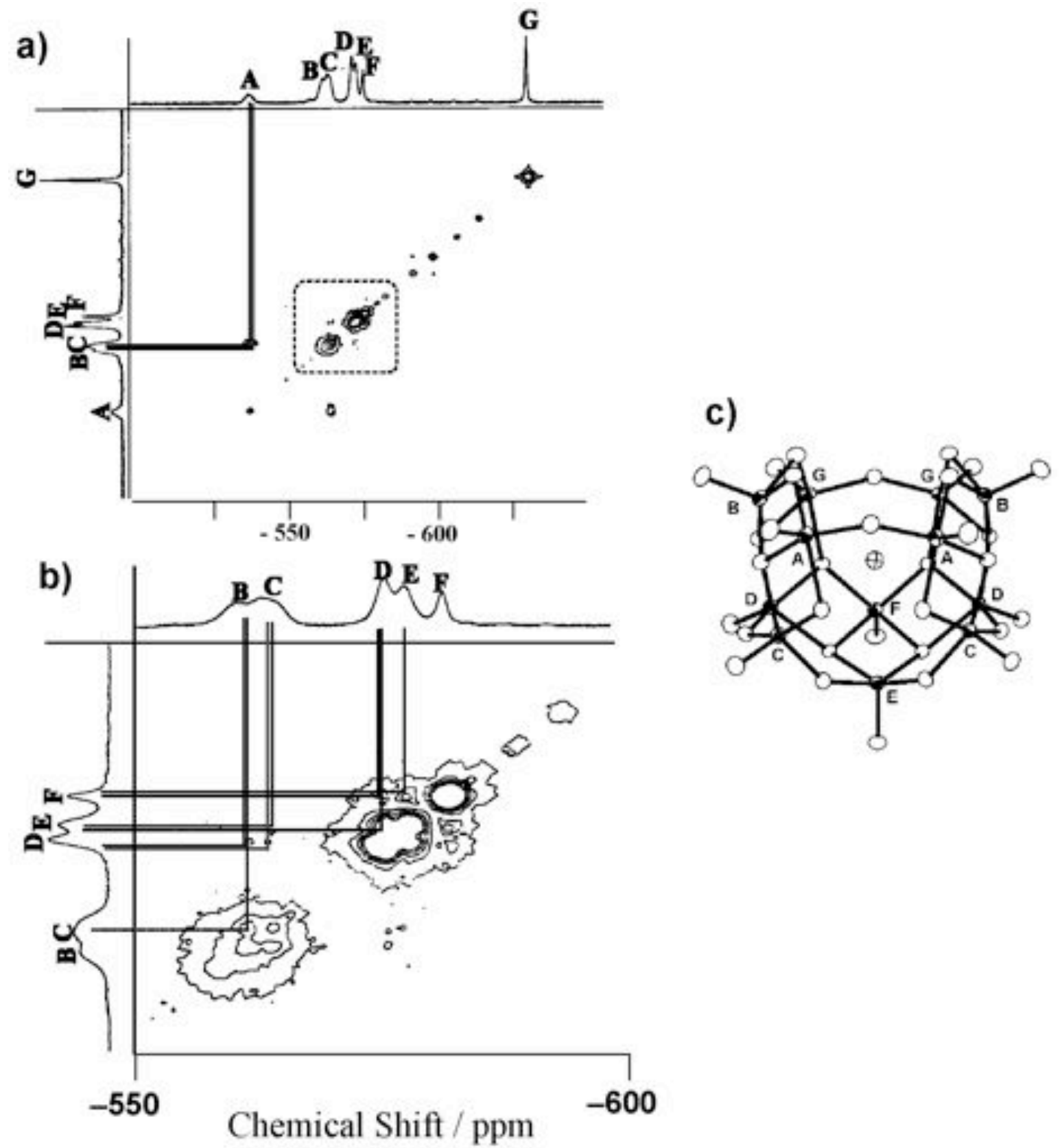

Figure $\mathrm{S} 4 .{ }^{51} \mathrm{~V}-{ }^{51} \mathrm{~V}$ COSY spectrum of $\mathbf{3}$ in acetonitrile- $d^{3}$ : a) $2 \mathrm{D}$ spectum of 3 ; b) expanded view of the 2D spectrum; c) one of the assignments to satisfy the correlations observed. 